\title{
HABITAT AND PHYTOCENOSIS CONDITIONS OF THE OCCURRENCE OF OSTERICUM PALUSTRE IN THE NATURA 2000 "LISI KĄT" SITE
}

\author{
Ewa Krasicka-KorczyńsKa, Tomasz Stosik, Maciej KorczyńsKi
}

\begin{abstract}
E. Krasicka-Korczyńska, T. Stosik, M. Korczyński, Department of Botany and Ecology, Faculty of Agriculture, University of Technology and Life Sciences in Bydgoszcz, Prof. S. Kaliskiego 7, 85-795 Bydgoszcz, Poland, e-mail: kra-kor@utp.edu.pl
\end{abstract}

(Received: September 16, 2013. Accepted: November 14, 2013)

\begin{abstract}
Ostericum palustre Besser is a species protected by the domestic and EU laws. In Poland it occurs in about 150 sites one of which is located in the area covered by Natura 2000 "Lisi Kąt". The population existing there, estimated as 35,000 individuals, covers the acreage of 342 ha. The species persists there mostly in over-dried and transformed-by-meadow-management reed beds with the share of Carex acutiformis and C. gracilis, in phytocenoses of Scheuchzerio-Caricetea nigrae with a large share of mosses, in overgrowing patches of the alliances of Molinion as well as sporadically within reed beds with Carex pseudocyperus. Its share in similar phytocenoses coincides with the reports in literature in the region of the Noteć Valley. In most cases those are heavily disturbed systems, transitional in nature, which must have been the reason for a relatively high level of species variation. The habitat preferences of Ostericum palustre, determined with Ellenberg's indicator values (L, T), correspond to the values optimal for the species. Soil, on the other hand, can be referred to as slightly acid, average fertile and mostly moist.
\end{abstract}

KEY WORDS: phytocenoses, "Lisi Kąt" PLH040026, Ostericum palustre, habitat conditions

\section{INTRODUCTION}

Ostericum palustre Besser (Angelica palustris (Besser) Hofm.) is a tall perennial representing family Apiaceae with a clearly furrowed stem and characteristic 2-3-fold frond leaves with slightly asymmetric, heart-like or trioval leaflets. The species, strictly protected (Rozporządzenie... 2012) has been identified as threatened across the country (ZARZYCKI \& MireK 2006) and at a brink of extinction (KAŹMIERCZAKOWA \& ZARZYCKI 2001). Upon Poland joining the European Union, it is also protected by the provisions of Habitats Directive (Council Directive... 1992).

In Poland Ostericum palustre occurs in about 150 sites. Some have failed to be confirmed, some are already considered historic. The greatest density of the sites of Ostericum palustre is observed in the area of the Wielkopolskie Lakeland, Kujawskie Lakeland, Mazowsze, Podlasie, Lubelska Upland, Małopolska Upland, as well as north-eastern part of the Sandomierska Valley (NoBis \& NoBis 2009).

Recently there have been also located new places where the species often forms numerous popula- tions (Michalska-Hejduk \& Kopeć 2010, Piwowarski \& BIELECKI 2012). It concerns e.g. the Noteć Valley and its region (KRASICKA-KorcZý́sKa 2007, 2008, KRASICKA-KORCZYŃSKA et al. 2012 a, 2012 b) a part of large which has not been yet considered in the Atlas of the distribution of vascular plants of Poland (ZajĄC $\&$ ZająC, eds 2001). The species can be met further north in the Tuchola Pinewoods (KrasicKa-KorcZYŃsKA unpublished). At all the sites of Natura 2000 in the Noteć Valley, the Bydgoszcz Canal and Szubińsko-Łabiszyńska Plateau one of the objects of protection are the populations of Ostericum palustre. One of them is the site of Natura 2000 "Lisi Kąt" (Fig. 1). In terms of administrative division, it is located in the commune of Kcynia and Nakło nad Notecią in the Kujawsko-Pomorskie Province. The geobotanic regionalisation locates it in the Brandenburg-Wielkopolska Division, Noteć-Lubuskie Region, the Chodzież District and Szubin Sub-District (Matuszkiewicz 1993). It covers mostly private land and a piece owned by the Szubin Forest Inspectorate.

The site covers a side valley going down to the Noteć River valley with height differences reaching 


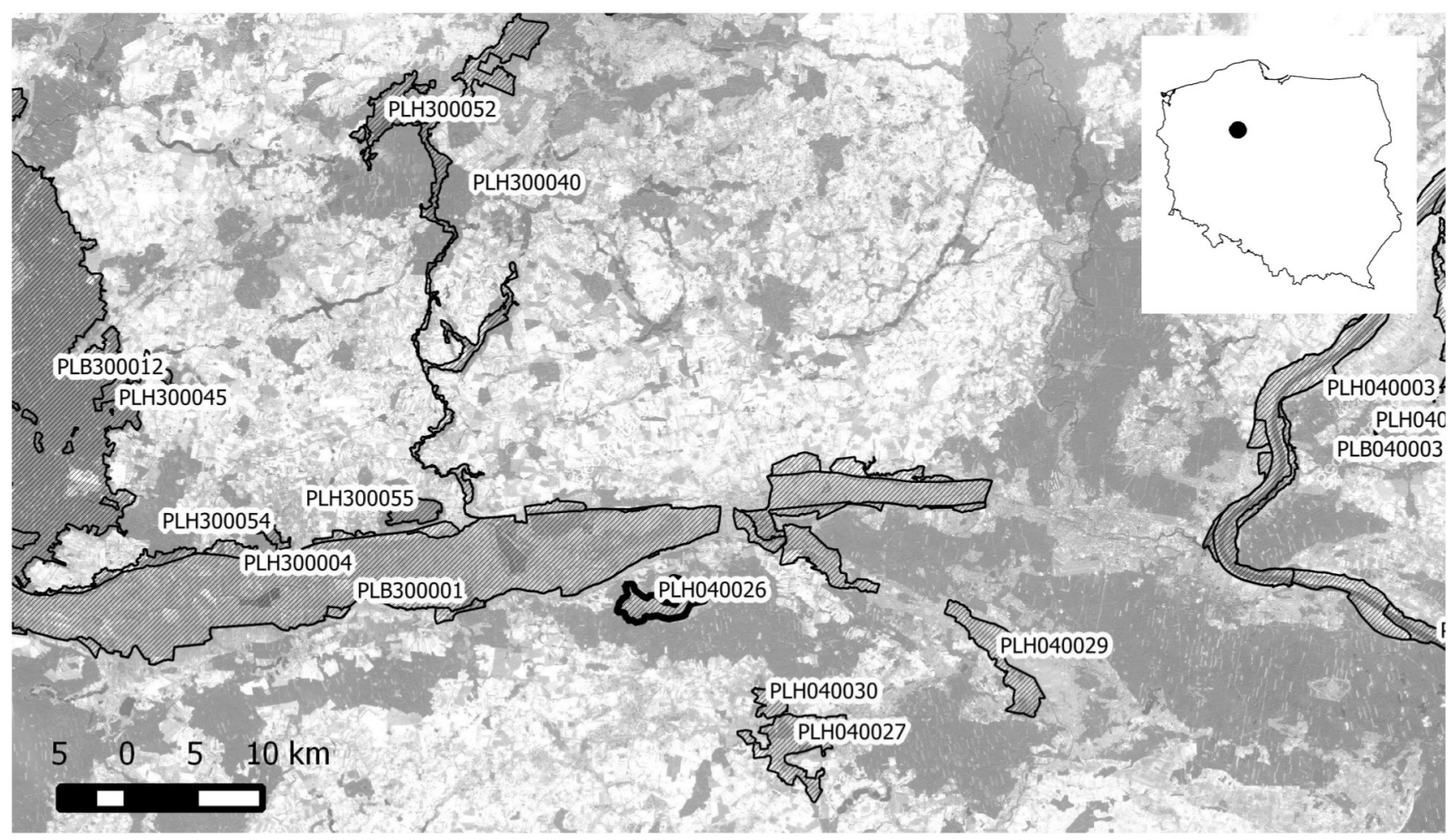

Fig. 1. "Lisi Kąt" PLH040026 (contour in bold) against other sites of Natura 2000 in the region

up to $20 \mathrm{~m}$. It is dominated by peat soils with an underlying layer of lake marl. The morainal hills are the only ones where rusty soils occur, and the locations of Jeziornica, Studzienki and Wisławica are found on sand formations.

The Standard Data Form (SDF) of 2007 lists five nature habitats and as for the plant species provided in Annex II of Council Directive 92/43/EEC (1992), there have been considered a well-preserved population of Ostericum palustre. As part of the works into the protection measures plan launched in 2012, there has been verified e.g. its preservation state and determined further protection prospects. Based on the documentation material collected, there have been presented habitat and phytocenosis conditions of the occurrence of Ostericum palustre at the site of Natura 2000 "Lisi Kąt".

\section{MATERIAL AND METHODS}

The documentation material is made up by 14 phytosociological relevés, made following the Braun-Blanquet method in the places of the occurrence of Ostericum palustre in the 2012 vegetation season within the borders of Natura 2000 "Lisi Kąt". The names of the vascular plants have been taken from MireK et al. (2002), and as for Bryophytes, the publication by OcнYra et al. (2003) was used. Phytocenoses were grouped and presented in phytosociological table according to the report by MatuszKiewicz (2002). To present the spectrum of phytocenoses with a share of Ostericum palustre with- in the entire set there was determined the species group value, considering both the number of the occurrences of respective taxa and their cover factor. For each relevé the Shannon-Wiener species diversity index value was calculated: $\mathrm{H}^{\prime}=-\Sigma \mathrm{pi} \log _{2} \mathrm{p}_{\mathrm{i}}$, where: $\log _{2}-\operatorname{logarithm}$ with Euler's number $2, \mathrm{p}_{\mathrm{i}}=$ percentage of cover of a given species (ni/N) (KREBS 2009).

Based on the Ellenberg's indicator values, habitat indices were calculated: L - light, $\mathrm{T}$ - thermal, $\mathrm{F}(\mathrm{M})$ - soil moisture, R - soil acidity and $\mathrm{N}$ - trophism (ELLENBERg et al. 1992).

\section{RESULTS AND DISCUSSION}

In 14 phytosociological relevés a total of 104 plant species, including four Bryophytes species was noted. In terms of phytosociological classification, they represent a dozen or so classes. The highest group value is reached by the species representing class Molinio-Arrhenatheretea (60 species), which accounts for more than $60 \%$ of all the taxa. There is also a clear share of species from class Phragmitetea with 13 species and the group value at the level of 12.8. The species from class Scheuchzerio-Caricetea nigrae, occurred 18 times, which translates into the index value analysed at the level of 5.5. The other groups of taxa are of little importance and assume the values from 0.3 to more than 2 (Fig. 2).

The phytosociological relevés given in Table 1 made it possible to differentiate between four phytocenosis patterns. In the community with order Mag- 


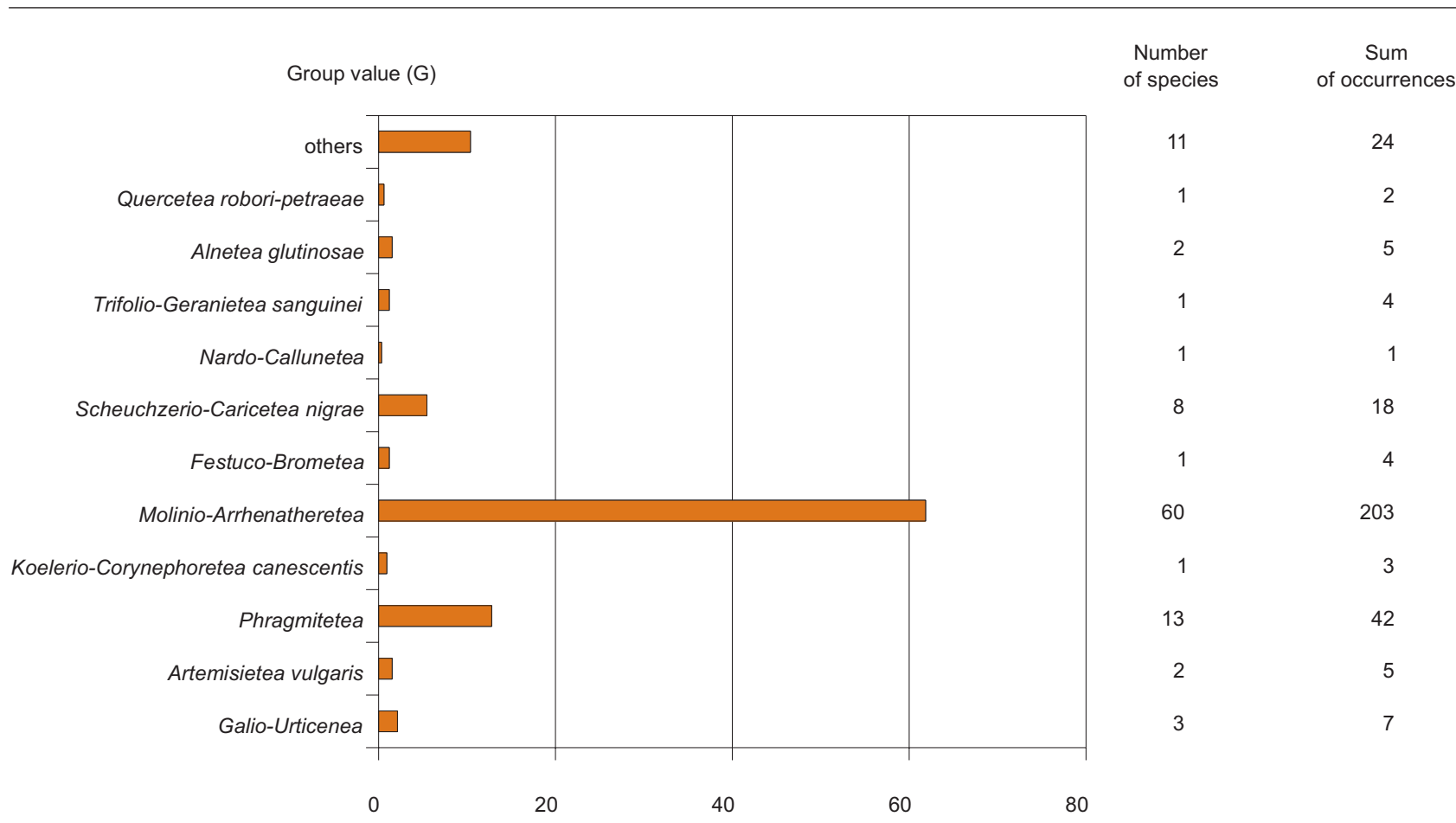

Fig. 2. Group value of the species which occur in the phytocenoses with Ostericum palustre in the site of Natura 2000 "Lisi Kąt"

nocaricion, with the dominance of Carex (Carex acutiformis, C. gracilis) Ostericum palustre reaches the cover up to $20 \%$ (Table 1 , column 1-6). However, those are the patches clearly overdried and changed as a result of the economic use, which points to a high share of the species representing class Molinio-Arrhenatheretea, mostly dominated by Festuca rubra. Communities of that type have been often described in literature (FIJAŁKOWSKI \& CHOJNACKA-FIJAŁKOWSKA 1982, BRÓż et al. 2002, KrasickA-KorczyŃSKA 2007, 2008, NoBIs et al. 2008, Michalska-Hejduk \& Kopeć 2010).

The following group of relevés documents phytocenoses with Carex nigra: class Scheuchzerio-Caricetea nigrae, with the most important species being: Carex panicea, Juncus articulatus and Triglochin palustris as well as mosses - mostly Drepanocladus aduncus. One comes across the Early Marsh Orchid (Dactylorhiza incarnata) quite frequently. Ostericum palustre reaches here up to $5 \%$ of the cover. The phytocenosis structure is supplemented by a large group of species characteristic for Caricion elatae All. as well as meadows, especially moist meadows, similarly as in other regions (KRASICKA-KORCZYŃSKA 2007, 2008, NoBis \& PiWOWARCZYK 2008).

Phytocenoses with a dominance of species from the alliance of Molinion as well as Filipendulion (Table 1, column 11-13) get formed on the non-used meadow areas, which is seen from a clear share of nitrophilic species, e.g. Eupatorium cannabinum, Urtica dioica and Carduus crispus. Ostericum palustre here reaches the abundance not higher than 5\%. Its share in phytocenoses from the alliance of Molinion, e.g. in the association of Selino-Molinietum caeru- leae is confirmed by GrYNIA (1962), KĘPCZYŃSKI et al. (1991), ZAŁUSKI (2004), NoBIs et al. (2008) as well as Michalska-Hejduk \& Kopeć (2010). The species also occurs in the phytocenoses from the alliance of Filipendulion (SUDNIK-WóJCIKOWSKA 1981, ZAŁUSKI 2004, Bróż \& Podgórska 2006, Nobis \& PiwowarCZYK 2008).

In the site of the Natura 2000 "Lisi Kąt" Ostericum palustre with an inconsiderable share, there was also noted in the community with Carex pseudocyperus, as well as in the patches with Typha angustifolia, Equisetum fluviatile and Galium palustre, representing class Phragmitetea.

Generally the optimum occurrence of Ostericum palustre on considered to be meadow communities from class Molinio-Arrhenatheretea (CZARNA \& ZAŁUSKI 2001, ZARZYCKI et al. 2002, ZAŁUSKI 2004, NoBIs 2008) where it occupies mostly extensively used meadows from the alliance with Molinion (GRYNIA 1962, KĘPCZYŃSKI \& ZAŁUSKI 1991, NobIs and PIWOWARCZYK 2008) as well as in phytocenoses from the alliances with Calthion (GRYNIA 1962, KĘPCZYŃSKI \& ZAŁUSKI 1991, ŻuKowski et al. 1995, ZAŁUsKi 2004, Nobis et al. 2008, Michalska-Hejduk \& Kopeć 2010).

In the Noteć River Valley Ostericum palustre occurs most frequently in the reed-bed communities with Carex nigra, C. acutiformis, C. gracilis, C. disticha (KRASICKA-KORCZYŃSKA 2007), in the community of Poa pratensis-Festuca rubra (KRASICKA-KORCZYŃSKA 2007, 2008) as well as on neglected meadows of Molinietum caeruleae (All. Molinion) with dominant purple moor grass and a considerable share of Laserpitium prutenicum (STOsIK - unpublished). 
Table 1. Phytocenoses with a share of Ostericum palustre in the site of Natura 2000 "Lisi Kąt"

\begin{tabular}{|c|c|c|c|c|c|c|c|c|c|c|c|c|c|c|}
\hline No of relevé & 1 & 2 & 3 & 4 & 5 & 6 & 7 & 8 & 9 & 10 & 11 & 12 & 13 & 14 \\
\hline Syntaxonomical unit & $\mathrm{A}$ & A & A & A & A & A & B & $\mathrm{B}$ & $\mathrm{B}$ & $\mathrm{B}$ & $\mathrm{C}$ & $\mathrm{C}$ & $\mathrm{C}$ & $\mathrm{D}$ \\
\hline Date & 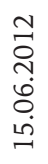 & 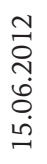 & \begin{tabular}{l}
$\stackrel{1}{0}$ \\
\multirow{N}{0}{} \\
$\ddot{0}$ \\
$\dot{0}$
\end{tabular} & 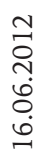 & 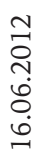 & 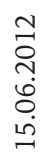 & 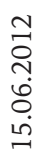 & 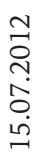 & 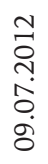 & 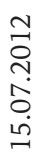 & 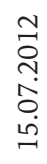 & 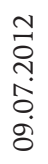 & 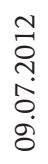 & 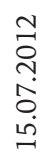 \\
\hline
\end{tabular}

Cover of herb layer (c) in all relevés $=100 \%$

Cover of mosses layer (d)

Number of species in relevé

$\begin{array}{cccccccccccccc}- & - & - & - & - & 20 & 50 & 30 & 40 & 40 & - & - & - & - \\ 28 & 20 & 20 & 16 & 18 & 22 & 21 & 44 & 34 & 21 & 11 & 17 & 19 & 17\end{array}$

Trees and shrubs

Salix cinerea c

Alnus glutinosa c

Ch. Cl. Galio-Urticenea

Eupatorium cannabinum

Urtica dioica

Epilobium hirsutum

Carduus crispus

Glechoma hederacea

Ch. All. Magnocaricion

Carex acutiformis

Carex gracilis

Carex appropinquata

Carex rostrata

Galium palustre

Scutellaria galericula

Lysimachia thyrsiflora

Carex pseudocyperus

Ch. All. Phragmition

Rorippa amphibia

Typha angustifolia

Ch. Cl. Phragmitetea

Equisetum fluviatile

Rumex hydrolapathum

Phragmites australis

Ch. All. Calthion

Cirsium oleraceum

Geum rivale

Carex cespitosa

Polygonum bistorta

Epilobium palustre

Caltha palustris

Scirpus sylvaticus

Myosotis scorpioides

Senecio aquaticus

Juncus effusus

Ch. All. Molinion

Molinia caerulea

Briza media

Ch. All. Filipendulion

Lythrum salicaria

Valeriana officinalis

Hypericum tetrapterum

Lysimachia vulgaris

Filipendula ulmaria

Veronica longifolia

Thalictrum flavum

Ch. O. Molinietalia

Ostericum palustre

Lychnis flos-cuculi

Deschampsia caespitosa

\begin{tabular}{|c|c|c|c|c|c|c|c|c|c|c|c|c|c|}
\hline 2 & 4 & 4 & 4 & 3 & & & . & . & . & + & 2 & 2 & \\
\hline$\dot{.}$ & . & . & $\dot{0}$ & 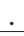 & 3 & 4 & + & + & . & . & $\cdot$ & . & . \\
\hline . & . & . & . & . & . & + & . & . & 3 & 3 & . & . & \\
\hline+ & . & . & . & . & . & + & 1 & 1 & . & . & . & . & 1 \\
\hline . & + & . & . & . & . & 1 & 1 & 1 & + & . & . & . & 3 \\
\hline . & . & . & . & . & . & + & . & . & + & . & + & + & + \\
\hline$\cdot$ & $\cdot$ & $\cdot$ & . & . & . & 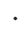 & . & + & . & . & . & . & + \\
\hline . & . & . & . & . & . & . & . & . & . & . & . & . & 4 \\
\hline
\end{tabular}

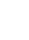


Table 1. cont.

\begin{tabular}{|c|c|c|c|c|c|c|c|c|c|c|c|c|c|c|}
\hline No of relevé & 1 & 2 & 3 & 4 & 5 & 6 & 7 & 8 & 9 & 10 & 11 & 12 & 13 & 14 \\
\hline Syntaxonomical unit & $\mathrm{A}$ & $\mathrm{A}$ & $\mathrm{A}$ & $\mathrm{A}$ & $\mathrm{A}$ & $\mathrm{A}$ & $\mathrm{B}$ & $\mathrm{B}$ & $\mathrm{B}$ & $\mathrm{B}$ & $\mathrm{C}$ & $\mathrm{C}$ & $\mathrm{C}$ & $\mathrm{D}$ \\
\hline Date & $\begin{array}{l}\text { ㄱ. } \\
\stackrel{1}{1} \\
\ddot{\theta} \\
\dot{n}\end{array}$ & 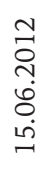 & 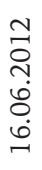 & 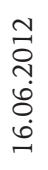 & 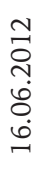 & 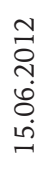 & 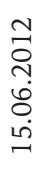 & 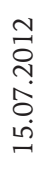 & 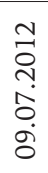 & 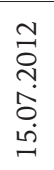 & 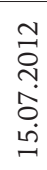 & 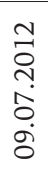 & 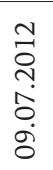 & 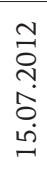 \\
\hline Lotus uliginosus & + & . & + & . & . & . & . & 3 & + & . & . & . & . & . \\
\hline Cirsium palustre & . & . & . & . & . & . & 1 & + & + & . & + & . & . & . \\
\hline Equisetum palustre & . & . & . & . & . & 1 & . & . & . & 1 & . & . & . & . \\
\hline Angelica sylvestris & . & . & . & . & . & . & . & + & . & . & . & . & . & . \\
\hline Climacium dendroides $\mathrm{d}$ & . & . & . & . & . & 2 & . & . & . & . & . & . & . & . \\
\hline \multicolumn{15}{|l|}{ Ch. All. Arrhenatherion } \\
\hline Achillea millefolium & + & + & 1 & + & 2 & + & + & 1 & + & + & . & . & 1 & . \\
\hline Galium mollugo & 1 & . & + & 2 & + & + & . & . & . & . & . & . & . & . \\
\hline Arrhenatherum elatius & + & . & + & . & . & + & . & + & . & . & . & . & . & . \\
\hline Daucus carota & 1 & . & . & . & . & 1 & . & . & . & . & . & . & . & . \\
\hline Heracleum sibiricum & + & . & . & . & . & . & . & . & . & . & . & . & . & . \\
\hline Dactylis glomerata & + & . & . & . & . & . & . & . & . & . & . & . & . & . \\
\hline
\end{tabular}

\section{Ch. Cl. Molinio-Arrhenatheretea}

Festuca rubra

Ranunculus acris

Holcus lanatus

Anthoxanthum odoratum

Plantago lanceolata

Avenula pubescens

Poa trivialis

Rumex acetosa

Trifolium pratense

Cerastium holosteoides

Cardamine pratensis

Potentilla anserina

Lathyrus pratensis

Centaurea jacea

Festuca pratensis

\begin{tabular}{|c|c|c|c|c|c|c|c|c|c|c|c|c|}
\hline 3 & 2 & 2 & 2 & 2 & 3 & 2 & . & 1 & . & . & . & . \\
\hline+ & + & . & + & . & + & . & + & + & . & . & . & . \\
\hline+ & + & + & + & 1 & . & . & 1 & . & . & . & . & . \\
\hline 1 & + & . & . & . & + & . & . & . & . & . & . & . \\
\hline+ & 1 & + & . & 1 & 1 & . & . & . & . & . & . & . \\
\hline 1 & . & 1 & + & . & 1 & . & . & . & . & . & . & . \\
\hline+ & . & . & 2 & . & 1 & . & 2 & 2 & . & . & . & . \\
\hline & . & . & + & + & + & . & + & . & . & . & . & . \\
\hline 3 & + & . & . & . & + & . & . & . & . & . & . & . \\
\hline . & . & . & $\cdot$ & + & + & . & . & . & . & . & . & . \\
\hline . & . & $\cdot$ & . & . & . & . & . & + & + & . & . & . \\
\hline . & . & + & . & 1 & . & . & + & + & + & . & . & . \\
\hline & - & $\cdot$ & $\cdot$ & . & . & - & . & . & . & - & + & + \\
\hline & + & . & . & . & . & . & . & . & + & . & . & . \\
\hline & . & . & . & . & . & . & + & . & 2 & . & . & . \\
\hline
\end{tabular}

Ch. Cl. Scheuchzerio-Caricetea nigrae

Carex nigra

Dactylorhiza incarnata

Triglochin palustris

Juncus articulatus

Carex panicea

Eriophorum angustifolium

Parnassia palustris

Viola palustris

Calamagrostis stricta

Drepanocladus aduncus

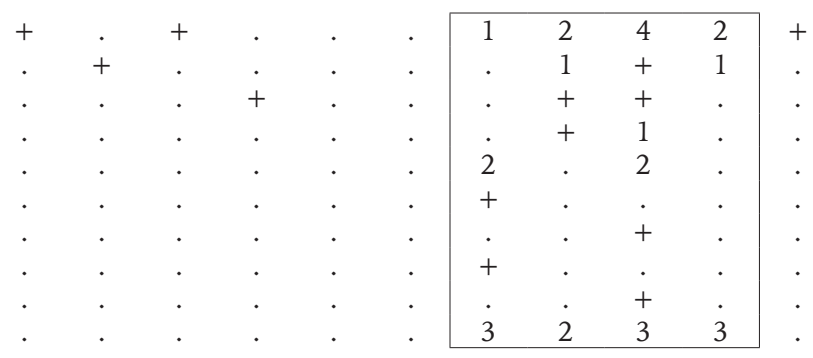

\section{Ch. Cl. Alnetea glutinosae}

Solanum dulcamara

Lycopus europaeus

\section{Accompanying: \\ Galium verum \\ Polygonum amphibium \\ Plagiomnium cuspidatum \\ Tomentypnum nitens \\ Medicago lupulina \\ Mentha $\times$ verticillata \\ Mentha aquatica}

Sporadic taxa: Bellis perennis $1(+)$, Cardaminopsis arenosa $5(+)$, Carex hirta $8(1)$, Galeopsis tetrahit $8(+)$, Hypericum maculatum $3(+)$, Juncus bufonius $5(+)$, Mentha arvensis $5(2)$, Odontites serotina $5(+)$, Plantago major $5(+), 9(+)$, Plantago media $1(+), 4(+)$, Poa pratensis 9 (1), Potentilla reptans $8(+)$, Prunella vulgaris $9(+)$, Ranunculus repens $8(+)$, Trifolium repens $1(+), 9(+)$, Valeriana dioica $7(1)$, Veronica scutellata $14(+)$, Vicia cracca $8(+)$.

Syntaxonomical units: A (relevé 1-6) Magnocaricion with Festuca rubra, B (relevé 7-10) Scheuchzerio-Caricetea nigrae, C (relevé 11-13) Molinion/Filipendulion - overgrown, D (relevé 14) community with Carex pseudocyperus. 


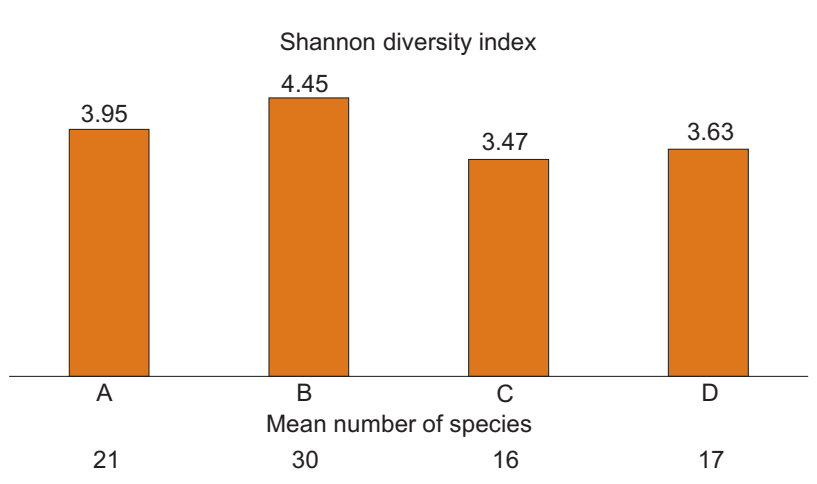

Fig. 3. Shannon species diversity in the phytocenoses with Ostericum palustre in the site of Natura 2000 "Lisi Kąt”: A - Magnocaricion with Festuca rubra, B - Scheuchzerio-Caricetea nigrae, C - Molinion/Filipendulion - overgrown, D - community with Carex pseudocyperus

Comparing the results recorded in the paper with the literature data, one can state that Ostericum palustre in the site of the Natura 2000 "Lisi Kąt" occurs in phytocenoses known from other regions, and the patches it occupies are often much transformed due to an intensive agricultural activity or abandoning it.

The Shannon index in the selected phytocenoses reaches the value of 3.47-4.45. The highest species diversity is shown for the patches representing class Scheuchzerio-Caricetea nigrae where, on average, there were found 30 plant species per relevé. In the communities dominated by high Carex the coefficient is slightly lower and it reaches 3.95, considering 21 species per patch. At the sites overgrowing with purple moor grass it reaches the level of 3.47 , and the number of species is lowest and it is six, on average (Table 1, Fig. 3).

The value of the species diversity index for the sites of that species found in the central Poland ranges from 2.6 to 3.2 , with the number of species per patch from 16 to 37 (Michalska-Hejduk \& Kopeć 2010). Generally at the site of "Lisi Kąt" as well as those in central Poland, the patches with a share of Ostericum palustre show a high biodiversity. Comparable results, which vary depending on the type of the community, were also recorded for the meadow communities of the San Valley (TrąBA et al. 2006). The index, for the meadows used in various ways in the central part of the Tuchola Pinewoods is similar; it is recorded beyond the extreme values, falling in the range of 2.4-3.0 (Sтолік 2010).

In terms of the light availability the habitat occupied by Ostericum palustre seems to meet its requirements. In all the communities the light index oscillates around 7 , which is at the same time the value attributed to the species. The thermal index, in most cases, is slightly lower than the optimum and it reaches the value of 5 . The community with Carex pseudocyperus is the only one where it is higher and it reaches around 6 .
The soil moisture index varies clearly. It assumes the lowest value in overdried and transformed-by-meadow-economy patches with Carex acutiformis and C. gracilis (slightly over 6.5), which, however, allows the species for a quite high cover factor value. The value considered optimal is referred to by the calculations made for the phytocenoses marked as B and C (Fig. 4). Both in Scheuchzerio-Caricetea nigrae and in overgrowing patches from the alliance with Molinion the value of the moisture index exceeds 7.5. As for the reed bed with Carex pseudocyperus, it points to a definitely higher moisture.

The soil acidity index in all the cases rather points to slightly acid soils, although in the case of phytocenoses from groups A and C it clearly moves towards the alkaline reaction.

The habitats of the phytocenoses analysed with Ostericum palustre are mid fertile and in the case of the patches of Carex with Festuca rubra (A) and Scheuchzerio-Caricetea nigrae (B) - poor indeed.

The values of the light and thermal indices only slightly differ from the species habitat preferences (ELLenberg et al. 1992). Also in the range of the habitat reaction the calculated values of the indices confirm the information reported in literature. The soil of the phytocenoses analysed, however, can be determined as, at most, mid fertile and mostly moist (ELLENBERG et al. 1992, CZARna \& ZaŁUSKi 2001, ZaŁUSKI 2004).

In the site of Natura 2000 "Lisi Kąt" one can encounter Ostericum palustre mostly in grasslands far away from agricultural farms. In most cases extensive farming is performed there, which involves a two-time cutting and not too high fertilisation. The patches often neighbour with, created as a result of land amelioration failure, vast All. Caricion elatae and specific reed beds (Fig. 5). The range of the sites occupied by Ostericum palustre is limited mostly by a gradual decrease in the moisture of the topsoil as well as more intensive farming on the plots located higher. A threat is also posed by the habitat fragmentation, resulting from irregular use of respective surfaces and, on the other hand, sporadic ploughing-in, under-sowing, rolling and FYM fertilisation.

At present the population of Ostericum palustre in Natura 2000 "Lisi Kąt" site is estimated as about 35,000 individuals in the area of 342 ha. The species occurs sometimes with a quite high cover factor, reaching a dozen or so or more percent. Usually, however, it records a few-percent cover in the phytocenosis (Table 1). One can assume that the population, in the case of maintaining the agricultural activity, excluding aggressive measures (ploughing-in, herbicide treatment), is not threatened, which should be enhanced by the new Rural Areas Development Program and following the Protective Measures Plan of the site of Natura 2000. 
L

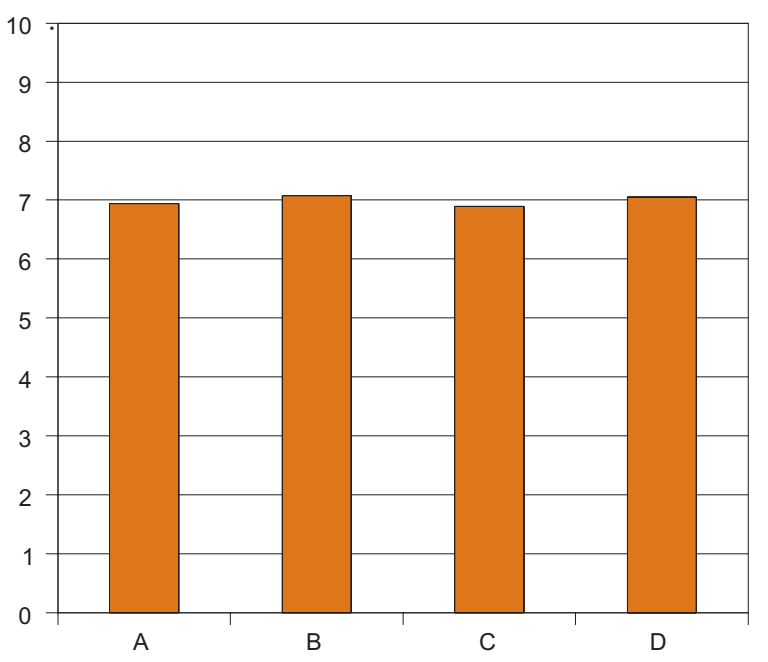

$F(M)$

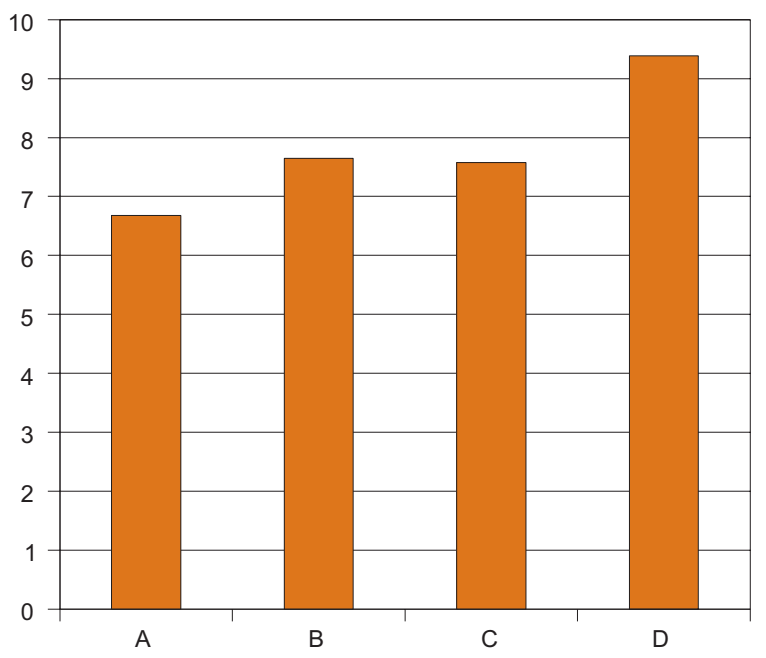

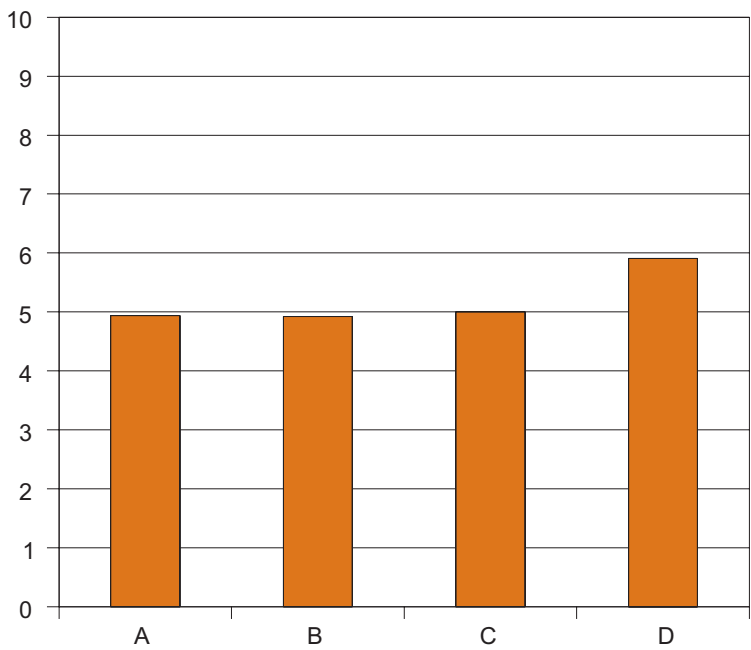

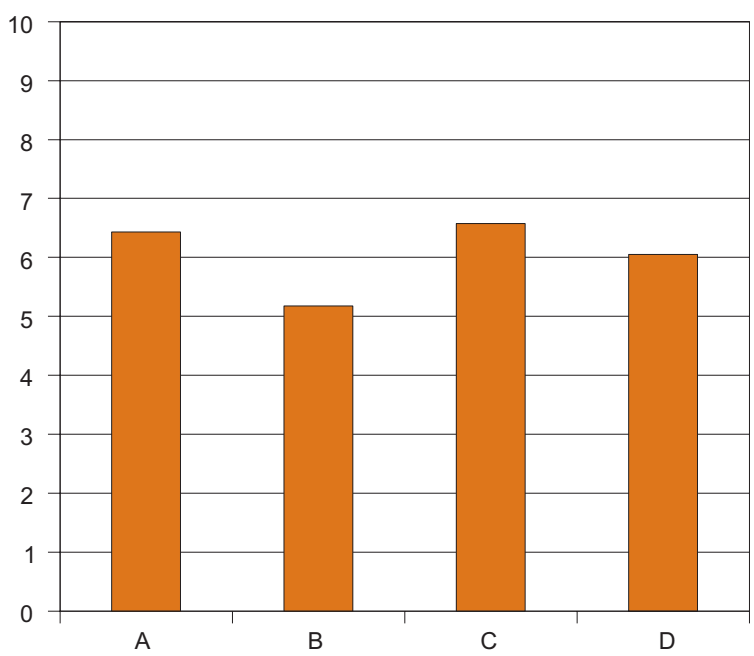

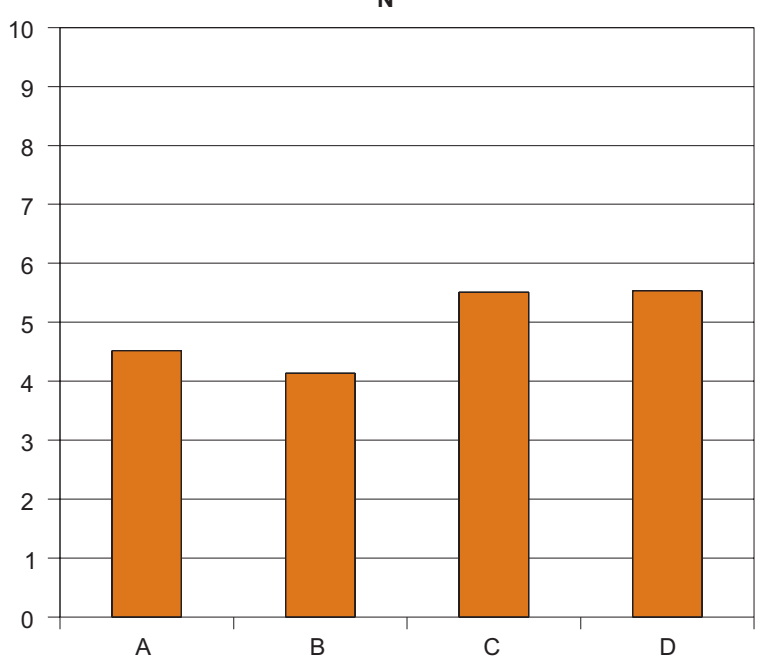

Indices:

$\mathrm{L}$ - light

$T$ - thermal

$\mathrm{F}(\mathrm{M})$ - soil moisture

$\mathrm{R}$ - soil acidity

$\mathrm{N}$ - trophism

Syntaxonomical units:

A - Magnocaricion with Festuca rubra

B - Scheuchzerio-Caricetea nigrae

C - Molinion/Filipendulion

D - community with Carex pseudocyperus.

Fig. 4. Value of the habitat indices of the communities with Ostericum palustre in the site of Natura 2000 "Lisi Kąt" 


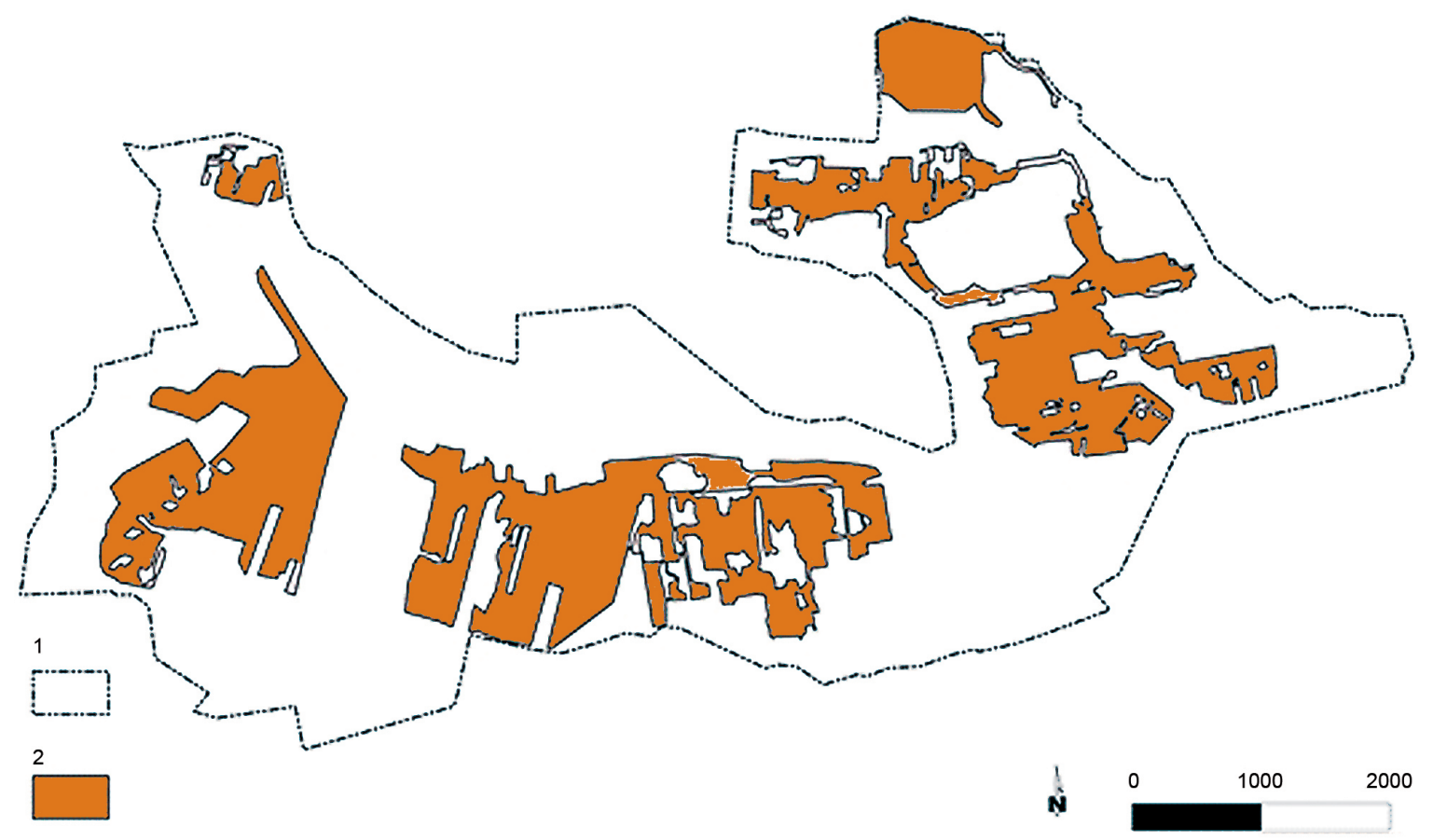

Fig. 5. Distribution of the sites with Ostericum palustre in the site of Natura 2000 "Lisi Kąt", 1 - borders of the site, 2 - habitats with Ostericum palustre

\section{CONCLUSIONS}

The site of Natura 2000 "Lisi Kąt" PLH040026 protects a large population of Ostericum palustre. On average there are almost 100 individuals of that species per ha.

The phytosociological studies have made it possible to determine phytocenoses where it occurs. Those are mostly the communities known from other regions, such as patches of the alliance of Molinion as well as phytocenoses frequent in the Noteć Valley, as Scheuchzerio-Caricetea nigrae and reed beds with Carex acutiformis and C. gracilis. Sporadically Ostericum palustre are met in the community with Carex pseudocyperus.

The species diversity of the patches with Ostericum palustre reaches a high level in the site of "Lisi Kąt", especially in the case of patches with Scheuchzerio-Caricetea nigrae, where it reaches up to 4.45 for 30 species per patch.

In most cases, defined with the indicator values, the features of the habitat occupied by Ostericum palustre in the site of Natura 2000 "Lisi Kąt", confirm the species habitat preferences reported in literature. Ostericum palustre prefers mid fertile and moist soils.

\section{REFERENCES}

Bróż E., Nobis M., Piwowarczyk R. (2002): Nowe stanowisko Ostericum palustre (Umbelliferae) na Przedgórzu Iłżeckim (Wyżyna Małopolska).
Fragmenta Floristica et Geobotanika Polonica 9: 379-380.

Bróż E., PodgórsKa M. (2006): Starodub łąkowy Ostericum palustre Besser na Wyżynie Małopolskiej. Chrońmy Przyrodę Ojczystą 62, 3: 3-12.

Czarna A., Zatuski T. (2001): Angelica palustris (Besser) Hoffm. Starodub łąkowy. In: R. Kaźmierczakowa, K. Zarzycki (eds). Polska czerwona księga roślin. Paprotniki i rośliny kwiatowe. Instytut Botaniki im. W. Szafera PAN i Instytut Ochrony Przyrody, PAN. Kraków: 277-279.

Council Directive 92/43/EEC of 21 May 1992 on the conservation of natural habitats and of wild fauna and flora (OJ L 206, 22.7.1992, p. 7).

Ellenberg H., Weber H. E., Düll R., Wirth V., WerNer W., Paulissen D. (1992): Zeigerwerte von Pflanzen in Mitteleuropa. Scripta Geobotanica 18, 2: 5-258.

Fijąkowski D., Chojnacka-FijaŁkowska E. (1982): Stosunki fitosocjologiczne i florystyczne projektowanego rezerwatu torfowiskowego Wieprzec pod Zamościem. Annales UMCS, Sect. C, 37: 255-269.

GrYNIA M. (1962): Łąki trzęślicowe Wielkopolski. Prace Komisji Nauk Rolniczych i Komisji Nauk Leśnych PTPN 13, 2: 145-269.

KaźmierCZAKowa R., ZARZYCKI K., eds (2001): Polska czerwona księga roślin. Paprotniki i rośliny kwiatowe. Instytut Botaniki im. W. Szafera PAN, Instytut Ochrony Przyrody, Kraków.

KęPCZYŃSKI K., ZAŁUSKI T. (1991): Zróżnicowanie roślinności łąk trzęślicowych w dolnym odcinku 
doliny Rakutówki. Acta Universitatis Nicolai Copernici, Biologia 36: 41-55.

KRASICKA-KORCZYŃSKA E. (2007): Share of Ostericum palustre Besser in biochores of agro-environmental programme POlb meadows. Botanische Jahrbucher für Systamatik, Pflanzengeschichte und Pflanzengeografie.

KRASICKA-KORCZYŃSKA E. (2008): Effect of the cutting date on blooming and fruit-bearing of Ostericum palustre Besser. Acta Agrobotanica 61, 1: 129-136.

KrasickA-KorczyŃSKA E., KorCZyŃsKi M., StosiK T., Paszek I., Kosowicz M. (2012 a): Obszar Natura 2000 Lisi Kąt PLH040026. In: Projekty planów zadań ochronnych dla obszarów Natura 2000 na terenie województw kujawsko-pomorskiego i mazowieckiego. Województwo kujawsko-pomorskie. Uniwersytet Technologiczno-Przyrodniczy w Bydgoszczy, Bydgoszcz: 3-11.

Krasicka-KorczyŃsKa E., StosiK T., KorcZyŃski M. (2012 b): Wpływ użytkowania rolniczego na zróżnicowanie roślinności łąkowej w Dolinie Środkowej Noteci, na przykładzie łąk w Samostrzelu i Bninie. In: R. Rolbiecki, T. Barczak (eds). Biologiczne, ekologiczne i środowiskowe uwarunkowania produkcji rolniczej. Wydawnictwa Uczelniane Uniwersytetu Technologiczno-Przyrodniczego w Bydgoszczy, Bydgoszcz: 97-106. http://dx.doi.org/10.5586/aa.2008.017

KreBs, CH.J. (2009): Ecology: the experimental analysis of distribution and abundance. Benjamin Cummings, San Francisco.

Matuszkiewicz W. (2002): Przewodnik do oznaczania zbiorowisk roślinnych Polski. Wydawnictwo Naukowe PWN, Warszawa.

Matuszkiewicz J.M. (1993): Krajobrazy roślinne i regiony geobotaniczne Polski. Prace Geograficzne IGiPZ PAN, 158.

Michalska-Hejduk D., Kopeć D. (2010): Ecological and sociological spectrum of Ostericum palustre at new localities in central Poland. Biodiversity Research Conservation 17: 63-71. http://dx.doi. org/10.2478/v10119-010-0008-0

Mirek Z., Piękoś-Mirkowa H., Zając A., Zając M. (2002): Flowering plants and pteridophytes of Poland. A checklist. Vol. 1. Biodiversity of Poland. - Krytyczna lista roślin naczyniowych Polski. T. 1. Różnorodność biologiczna Polski. W. Szafer Institute of Botany, Polish Academy of Sciences, Kraków.

NoBIs M. (2008): Starodub łąkowy Ostericum palustre Besser. In: Z. Mirek, H. Piękoś-Mirkowa (eds). Czerwona księga Karpat polskich. Rośliny naczyniowe. Instytut Botaniki im. W. Szafera, Polska Akademia Nauk, Kraków: 276-277.

Nobis M., NoBIs A. (2009): 1617 Ostericum palustre Besser - starodub łąkowy. Monitoring gatunków i siedlisk przyrodniczych ze szczególnym uwzględnieniem specjalnych obszarów ochro- ny siedlisk Natura 2000. Wyniki monitoringu. GIOŚ, Warszawa: 10.

Nobis M., Nobis A., KozaK M. (2008): Występowanie Ostericum palustre (Apiaceae) w południowej Polsce. Fragmenta Floristica et Geobotanica Polonica 15, 1: 3-9.

Nobis M., Piwowarczyk R. (2008): The distribution, habitat preferences and size of population of Ostericum palustre Besser on the south-western limit of its occurrence in Poland. Nature Conservation 65: 43-49.

Ochyra R., Żarnowiec J., Bednarek-Ochyra H. (2003): Census catalogue of Polish mosses. W. Szafer Institute of Botany, Polish Academy of Sciences, Kraków.

PiwowARski B., Bielecki M. (2012): Nowe stanowisko Ostericum palustre (Apiaceae) na Wyżynie Małopolskiej. Fragmenta Floristica et Geobotanica Polonica 19, 1: 61-65.

RozPorZĄDZENIE Ministra ŚrodowisKa z dnia 5 stycznia 2012 r. w sprawie ochrony gatunkowej roślin. Dz.U. z dnia 20 stycznia 2012, poz. 81.

STosik T. (2010): Stan i uwarunkowania ochrony różnorodności biologicznej w przestrzeni rolniczej obszaru o niskim potencjale produkcyjnym. Zeszyty Problemowe Postępów Nauk Rolniczych 556: 975-985.

SuDNik-WójCikowsKa B. (1981): Rzadkie i interesujące gatunki roślin naczyniowych z obszaru Wielkiej Warszawy. Fragmenta Floristica et Geobotanica 27,4: 565-576.

Trąba Cz., Wolański P., Oklejewicz K. (2006): Różnorodność florystyczna wybranych zbiorowisk nieleśnych doliny Sanu. Annales UMCS. Sect. E. 61: 267-275.

ZAJĄC A., ZAJĄC M., eds (2001): Atlas rozmieszczenia roślin naczyniowych w Polsce. Pracownia Chorologii Komputerowej Instytutu Botaniki UJ, Kraków.

ZAŁUSKI T. (2004): Ostericum palustre Besser. In: B. Sudnik-Wójcikowska, H. Werblan-Jakubiec (eds). Poradnik ochrony siedlisk i gatunków Natura 2000. Tom 9. Gatunki roślin. Wydawnictwo Ministerstwa Środowiska, Warszawa: 160-163.

ZarZYcki K., Mirek Z., (2006): Red list of plants and fungi in Poland. Czerwona lista roślin i grzybów Polski. Instytut Botaniki im. W. Szafera PAN, Kraków.

ZarZYCKi K., TrZciŃSKa-TACiK H., RóŻAŃSKi W., SzeląG Z., Wołek J., Korzeniak U. (2002): Ecological indicator values of vascular plants of Poland. Biodiversity of Poland 2. W. Szafer Institute of Botany, Polish Academy of Sciences, Kraków.

Żukowski W., Latowski K., Jackowiak B., Chmiel J. (1995): Rośliny naczyniowe Wielkopolskiego Parku Narodowego. Prace Zakładu Taksonomii Roślin UAM w Poznaniu 4: 5-229. 